\author{
Aleksandra Joanna Smorawska \\ Towarzystwo Kultury Języka Oddział w Warszawie
}

\title{
Ostatnia Wieczerza popkultury
}

\begin{abstract}
Streszczenie
Oksymoroniczne zestawienie kultury popularnej z elementami należącymi do sfery sacrum jest jedną ze strategii shockvertisingu. Analiza występowania w reklamie drukowanej motywu znanego z Ostatniej Wieczerzy Leonarda da Vinci pokazuje, jak często uspółczesny przemysł reklamouy sięga po oswojone, pouszechnie rozpoznawalne przedstawienia należące do porządku sakralnego. Z zapożyczeń chętnie korzystają przedstawiciele rozmaitych branż, by za pomocą nawiązań do Ostatniej Wieczerzy promować produkty, miejsca, uydarzenia czy usługi. Reakcje towarzyszące pojawieniu się poszczególnych reklam unaoczniają, jak silne emocje wywołuje sięganie przez ich tuórców po elementy ze sfery sakralnej. Warto na mariaż sacrum i kultury popularnej spojrzeć nie tylko jako na chęć zurócenia uwagi znudzonego odbiorcy i szokowania za uszelką cenę, ale także szerzej - jako próbę postawienia ważnych pytań u debacie dotyczącej uspółczesności.
\end{abstract}

Słowa kluczowe: Ostatnia Wieczerza, reklama drukowana, kultura popularna, sacrum, shockvertising.

\section{The Last Supper of popculture}

\begin{abstract}
An oxymoronic relation between popular culture and the sacred is one of the strategies of shockvertising. The analysis of The Last Supper theme in printed advertisement shows how often the industry of advertising uses well-known and easily recognizable sacred symbols. Elements taken from the sacred sphere can be found in advertisements from various sectors, and also in different places, events and services. The reactions to analyzed advertisements show how strong emotions are related to shockvertising that uses sacred symbols. Research proves that it is valuable to look at the relation between popculture and the sacred not only as a way to simply shock, but also as an important voice in the debate about the present.
\end{abstract}

Keywords: The Last Supper, printed advertisement, popculture, the sacred, shockvertising.

\section{Wprowadzenie}

Mariaż sfery sakralnej z kulturą popularną można rozpatrywać na wielu płaszczyznach. Ramy artykułu choć wymagają drastycznego zawężenia pola badawczego, ukazują interesującą przestrzeń do analizy rozmaitych typów odwołań, które wydatnie służąc reklamowej persuazji, ukazują również jej skutki w życiu społecznym. Przedstawione 
rozuażania, sytuując komunikat reklamowy jako tekst kultury popularnej, mają na celu uskazanie sposobów wykorzystania Ostatniej Wieczerzy Leonarda da Vinci jako elementu sfery sakralnej adoptowanego na potrzeby działań reklamouych oraz ich konsekwencji.

\section{Terminologia i metodologia}

Istotne dla niniejszego wywodu kategorie to: reklama jako tekst kultury popularnej oraz sacrum. Kultura popularna jawi się jako przedmiot niejednorodny, charakteryzujący sferę życia społeczności lub cywilizacji ${ }^{1}$. Słownikowa definicja zuraca uwagę na stopniowe odejście od arystokratycznej krytyki kultury popularnej, choć nadal, by ją scharakteryzować, używa się „antynomicznych kategorii kultury elitarnej, wysokoartystycznej”2. Ważną, z punktu widzenia badania przekazów reklamouych cechą kultury popularnej, jest jej „dostępność inicjacyjna i łatwość osiągania komunikacyjnych kompetencji”.

Ponadto warte podkreślenia są funkcje spełniane przez kulturę popularną: terapeutyczna, regulacyjna, integracyjna oraz estetyczna ${ }^{4}$. W odniesieniu do przekazów reklamowych wszystkie funkcje, choć z różnym natężeniem, znajdują zastosowanie. Funkcja terapeutyczna, polegająca na eskapizmie, prowadzi do uaktyunienia emocji odbiorcy i przeżywania przezeń zastępczych doświadczeń. Ujawniająca się w kształtowaniu charakterystycznych dla danej kultury cech i wartości funkcja regulacyjna prowadzi do ich głębokiego zakorzenienia w świadomości członków danej grupy. Funkcja integracyjna kultury popularnej przejawia się w stwarzaniu „poczucia przynależności do grupy i przekonania o jej spójności, oraz [...] [uywoływaniu] jednolitych reakcji poprzez uspólne doświadczenia [...”ㄷ. Funkcja estetyczna jest zależna od biegłości technicznej twórcy, któremu, jak pokażą analizowane przykłady, zdarza się balansować na granicy łatwo przyswajalnego kiczu.

Ramy artykułu nie pozwalają na prześledzenie dziejów kultury popularnej, warto jednak uspomnieć, że popkultura, dawniej spychana na margines, w II połowie XX wieku zauważona jako niekoniecznie pasożytnicza narośl na kulturze wysokiej, w końcu XX wieku i w początkach wieku XXI zaczyna być traktowana jako „dynamiczny obszar wymiany znaków, rzeczy i wartości”‘. Poza dziedzinami tradycyjnymi, kultura popularna zaczyna obejmować „całokształt praktyk życiowych i zachowań publicznych, sytuacje potoczne [...], okazjonalną, płynną przestrzeń [...], ikonosferę i grafemikę [...], dźwięki

\footnotetext{
${ }_{1}$ Słownik literatury popularnej, red. T. Żabski, wyd. I, Towarzystwo Przyjaciół Polonistyki Wrocłauskiej, Wrocław 1997, s. 197.

2 Ibidem. Wyróżnienia u tekście za tekstem oryginalnym.

${ }^{3}$ Ibidem, s. 198.

${ }^{4}$ Ibidem, s. 199-200.

${ }^{5}$ Ibidem.

${ }^{6}$ Stownik literatury popularnej, red. T. Żabski, wyd. II, Wydawnictwo Uniwersytetu Wrocłauskiego, Wrocław 2006, s. 292.
} 
(glosy miasta), zapachy i smaki”’ Spośród bogactua kultury popularnej w tym artykule analizie zostaną poddane przekazy reklamowe.

Każdy z nas ,jest w jakiś sposób pop” i mniej lub bardziej świadomie przechadza się po „kolorouym dywanie popkultury”. Denis Scheck, definiując kulturę popularną, przywołał jej skojarzenie z jednej strony z pop-artem, z drugiej - z popcornem ${ }^{10}$. Temat niniejszego artykułu, dotykający ważnych aspektów popkultury, sytuuje się więc pomiędzy dziełem sztuki w galerii a ulicznym kioskiem z kukurydzą ${ }^{11}$.

Reklama ma suoje początki już u starożytności, zasadniczo wyróżnia się trzy okresy w jej dziejach: przedmarketingouy, informacji masowej oraz erę badań marketingowych $^{12}$. Biorąc pod uwagę ramy tekstu, warto zaznaczyć jedynie, że w połowie XX wieku rozpoczęła się ostatnia jak do tej pory faza, którą można spuentować stwierdzeniem, że proces odmasowienia reklamy prowadzi do coraz bardziej świadomego i precyzyjnego definiowania targetu przekazów reklamowych ${ }^{13}$. Aktualne jest natomiast twierdzenie, że „sprzedawca nie ponosi odpowiedzialności za łatwowierność kupującego”"

Tworząca się sieć uzajemnych zależności między reklamą a sztuką w latach 90. XX wieku prowadzi do tego, że reklama „sama siebie zaczyna definiować jako sztukę" ${ }^{15}$. Coraz bardziej popularna staje się strategia shockvertisingu, którego celem jest pewność, że zaszokowany odbiorca, wyrwany ze znudzenia i zniechęcenia reklamami, zapamięta dany przekaz. Jedną z dróg do stworzenia kontrowersyjnego, łatwego do zapamiętania komunikatu jest użycie w nim elementów charakterystycznych dla sfery sakralnej.

Pod pojęciem sacrum kryje się to, co święte, „,co specyficzne dla religii [...], w odróżnieniu od profanum"16. Świętość jako idea-matka religii zaistniała na przełomie XIX i XX wieku dzięki Marcelowi Maussowi. Nathan Söderblom twierdzil, że „świętość jest najważniejszym słowem religii; jest może nawet bardziej istotna od pojęcia Boga" ${ }^{17}$. Eliade był zdania, że religijny obraz świata człowiek archaiczny zbudował na opozycji

7 Ibidem.

${ }^{8}$ W.J. Burszta, W. Kuligouski, Dlaczego kościotrup nie wstaje. Ponowoczesne pejzaże kultury, „Sic!", Warszawa 1999, s. 11.

${ }_{9}$ Ibidem, s. 15.

${ }_{10}$ M. Krajewski, Kultury kultury popularnej, Wydaunictwo Naukowe UAM, Poznań 2005, s. 23.

${ }^{11}$ Ibidem.

12 M. Strużycki, T. Heryszek, Nowoczesna reklama na wspótczesnym rynku, Difin, Warszawa 2007, s. 16.

${ }_{13}$ Wiedza o reklamie, praca zbiorowa, Wydawnictwo Szkolne PWN, Warszawa-Bielsko-Biała 2009, s. 13. Niezuykle ciekawym u tym kontekście przykładem jest reklama elektronicznego różańca, dzięki któremu możemy usłyszeć „autentyczny głos Jana Pawła II” i razem z nim się modlić. Osoby zainteresowane kupnem tego religijnego gadżetu nie skojarzą zapewne faktu, że lektorem w reklamie jest znany z antyklerykalnych wystąpień Jakub Wątły, por. https://www. youtube.com/watch?v=bGxA87i6KA4 (dostęp: 14.10.2017) oraz rozmowa autorki tego artykułu z J. Wątłym.

${ }_{14}$ Wiedza o reklamie, op. cit., s. 14.

${ }^{15}$ Ibidem, s. 60.

${ }^{16}$ Maty stownik religioznawczy, red. Z. Poniatouski, Wiedza Pouszechna, Warszawa 1969, s. 388.

${ }_{17}$ Cytat za: Religia. Encyklopedia PWN, t. 9, red. T. Gadacz, B. Milerski, Wydawnictuo Naukowe PWN, Warszawa 2003, s. 23. 
sacrum-profanum jako przeciustawieniu bytu i nie-bytu ${ }^{18}$, a święte może być tylko to, co unika styczności z profanum ${ }^{19}$. Ważne, że sacrum jest definiowane jako podstawowa kategoria religijna, ,przedmiot przeżycia (doświadczenia) religijnego, pouszechny przedmiot religijnego kultu, niezależnie od rodzaju i form religii” ${ }^{20}$. W zsekularyzowanym świecie sacrum podlega zasadniczym przemianom, często bywa przesunięte w „świeckie obszary kultury, które miały zastąpić religię"21. Wiek XX przyniósł sacrum „tworzone według potrzeb i upodobań ludzkich, na miarę człowieka; za sacrum uważa się niesprecyzowaną zasadę duchowego zaspokojenia potrzeby sensu życia; sacrum staje się narzędziem osobistej, duchowej czy psychicznej, realizacji”"22. Zasadne wydaje się pytanie, czy wizerunki kojarzone z sacrum zaprzęgnięte u służbę reklamie nie staną się pustymi znakami, niemającymi odniesień u sferze sakralnej.

\section{Ostatnia Wieczerza jako tekst kultury popularnej}

W dalszej części artykułu analizie zostaną poddane uybrane przykłady użycia motyuu malarskiego znanego z Ostatniej Wieczerzy Leonarda da Vinci. Obraz da Vinci to jedno z najsławniejszych i najważniejszych dzieł w historii malarstwa ${ }^{23}$, najczęściej odwiedzane pojedyncze dzieło sztuki na świecie ${ }^{24}$. Jest ono interesujące przede uszystkim jako często reprodukowany święty wizerunek w historii chrześcijaństwa ${ }^{25}$. W pouszechnej świadomości funkcjonuje nie tyle jako wielkie dzieło malarskie, ile obrazek dewocyjny i właśnie w tym znaczeniu będzie tu występował.

Oryginalny obraz poustał na zamówienie Lodovico il Moro, mediolańskiego księcia, jako dekoracja klasztoru Santa Maria Della Grazie w Mediolanie ${ }^{26}$. Ścienne malowidło o wymiarach 460 na 880 centymetrów ${ }^{27}$ przedstawia Jezusa zasiadającego przy stole w Wieczerniku w towarzystwie duunastu apostołów. Dzieło ilustruje moment, w którym Jezus zapowiada zbliżającą się zdradę, jakiej dokona jeden z jego uczniów ${ }^{28}$.

${ }^{18}$ Ibidem.

${ }^{19}$ Leksykon podstawowych pojęć religijnych. Judaizm. Chrześcijaństwo. Islam. red. A.T. Khoury, PAX, Warszawa 1998, s. 905.

${ }_{20}$ Powszechna Encyklopedia Filozofii, t. 8, Polskie Towarzystwo Tomasza z Akwinu, Lublin 2007, s. 889.

${ }^{21}$ Ibidem, s. 892.

${ }^{22}$ Ibidem. Z.J. Zdybicka, autorka definicji, tuierdzi, że sacrum utożsamia się z „przeżyciem ekstatycznym, które ma zapewnić uczucie ostatecznego spełnienia”, może nim być np. seks, por. ibidem.

${ }^{23}$ Leonadro da Vinci - „Ostatnia Wieczerza”, http://www.italia-italia.info/021_ultimacena. htm (dostęp: 8.08.2017).

${ }^{24}$ K. Niedałtowski, Zawsze Ostatnia Wieczerza, Wydawnictwo Książkowe Twój Styl, Warszawa 2006, s. 11.

${ }^{25}$ Ibidem, s. 210.

${ }^{26}$ Sztuka świata, t. 5, red. P. Trzeciak, Arkady, Warszawa 2004, s. 277.

${ }^{27}$ Ibidem.

${ }^{28}$ Por. słowa Jezusa „Zapraudę powiadam wam, że jeden z was mnie zdradzi”, B. Osińska, Sztuka i czas. Od prehistorii do rokoka, WSiP, Warszawa 2004, s. 152. 
Motyu znany przede wszystkim z Ostatniej Wieczerzy pędzla da Vinci często stawał się inspiracją dla twórców reklam. W dalszej części tekstu analizie zostaną poddane możliwie silnie zdywersyfikowane przykłady użycia Ostatniej Wieczerzy w reklamie drukowanej.

\section{Ostatnia Wieczerza w reklamie}

Archiwum Advertolog odnotowuje, że reklamowe nawiązania do Ostatniej Wieczerzy pojawiają się w 1999 roku $^{29}$, kiedy to plakatem opatrzonym hasłem „The Last Supper” przedstawiającym tonącego Titanica promowano festiwal kulinarny u Indiach ${ }^{30}$. Tragedia tonącego wycieczkowca dla wielu pasażerów rozegrała się u trakcie kolacji, która okazała się tą ostatnią. A może posiłki serwowane podczas wydarzenia miały się okazać tak pyszne, że warto przyjechać na festiwal nawet, gdyby miała to być ostatnia kolacja u życiu? Branżę restauracyjną reprezentuje także reklama niemieckiej restauracji i pizzerii „12 apostołów”'1. Stylizowane na dawne wnętrze z pustym stołem bez zasiadających za nim gości budzi oczywiste skojarzenia u kontekście zarówno nazuy restauracji, jak i wiadomości zostawionej na obrazie - podobnej do odręcznie napisanej kartki. Przekaz brzmi: „Jesteśmy tuż za rogiem” - jeśli więc Jezus i apostołowie na kolację udali się do rzeczonej restauracji, to my róunież powinniśmy.

W 2003 roku francuski dom mody Marithé et François Girbaud reklamował swoją działalność plakatem ${ }^{32}$, który przedstawia „ubrane w ciuchy reklamującej się firmy dzieuczyny [które] dość wiernie poutarzają układ i gesty uczniów Jezusa"’33. Na miejscu Jezusa zasiada modelka, a jedyny mężczyzna obecny na plakacie jest odurócony tyłem do oglądającego, także jako jedyny jest od pasa u górę nagi. Postaci zasiadające za designerskim, srebrzystym stołem zdają się skupione jedynie na doczesności. Uwagę przykuwają ich staranne stylizacje - perfekcyjne fryzury, modne ubrania, szczupłe, doskonałe ciała. Na pierwszy plan wysuwa się charakterystyczne dla obrazu da Vinci ustawienie postaci. Autor plakatu gra z widzem, nawiązując do znanego z malarstua przedstawienia, jednak nie robi tego w oczywisty sposób. Włącza się w debatę o sztuce i wzorcach u niej obecnych, o współczesności i płci. Odwraca porządek płci, nawiązując do hipotezy o tym, jakoby na obrazie da Vinci przedstawił dưunastu mężczyzn

\footnotetext{
${ }^{29}$ Advertolog nie wymienia reklamy z 1997 roku, która odbiła się szerokim echem. Chodzi o billboardy reklamujące nowego Volkswagena Golfa. Przedstawiają one trzynastu mężczyzn zasiadających za długim stołem, podpis głosi: „Radujmy się moi mili, oto bowiem narodził się nowy Golf", por. Ostatnia Wieczerza w popkulturze, http://www.joemonster.org/art/13690/ Ostatnia_Wieczerza_w_popkulturze (dostęp: 30.12.2010).

${ }^{30}$ http://www.advertolog.com/guestline-hotels/print-outdoor/last-supper-1812055/ (dostęp: 11.09.2017).

${ }^{31}$ http://wuw.advertolog.com/die-12-apostel/print-outdoor/the-last-supper-5638905/ (dostęp: 11.09.2017).

32 http://www.advertolog.com/marithe-francois-girbaud/print-outdoor/marithe-francois-girbaud-5392305/ (dostęp: 5.09.2017).

${ }^{33}$ M. Poprzęcka, Ciuchy i świętość, „Gazeta Wyborcza” 2005, 7-8 maja, s. 12.
} 
i kobietę - Marię Magdalenę ${ }^{34}$. Zadaje pytanie o to, czy w dzisiejszych czasach Jezus mógłby zafunkcjonować jako młoda, atrakcyjna i zadbana kobieta.

Historyk sztuki, Maria Poprzęcka, określa plakat mianem dzieła wysoce estetycznego, wysmakowanego, a nawet - nobliwego ${ }^{35}$. Taka ocena w kontekście sankcji, jakie spotkały twórców plakatu, wydaje się jednak odosobniona. W Mediolanie władze uzasadniały zakaz dystrybucji plakatu tym, że użycie symboli istotnych dla chrześcijaństua u proponowanym kontekście może spowodować obrazę i zgorszenie części społeczeństuaa ${ }^{36}$. Kościół katolicki we Francji doprowadził do wydania sądowego zakazu dystrybucji plakatu. Zgodnie z informacją podaną w telewizji BBC sąd motywował wydanie zakazu tym, że doszło do „nieuzasadnionego i agresyunego wtargnięcia w ludzkie wierzenia”37. Prawnik Thierry Massis tłumaczył, że trywializowanie świętości, które leżą u podstaw religii, prowadząc do moralnej przemocy jest zagrożeniem dla młodego pokolenia ${ }^{38}$.

Najciekauszym, twórczym przetworzeniem dzieła da Vinci, wydaje się plakat z 2007 roku promujący dwudziestą czwartą edycję corocznego Folsom Street Fair. Fred Alert, autor fotografii będącej kanwą plakatu, w miejscu, gdzie na obrazie zasiada Jezus, przedstawił półnagiego, czarnoskórego mężczyznę. Jest on otoczony przez dwanaście postaci $^{39}$. Zasiadają one za stołem suto zastawionym sadomasochistycznymi seks-zabawkami ${ }^{40}$. W centralnym punkcie stołu leży flaga zaprojektowana przez Tony'ego DeBlase - Leather Pride Flag, będąca symbolem „skórzaków”41.

Pojauienie się plakatu promującego Folsom Street Fair odbiło się szerokim echem. Sprzeciwiano się wykorzystaniu motyuru znanego z Ostatniej Wieczerzy na plakacie, który protestujący uznali za uosobienie biblijnej Sodomy i Gomory ${ }^{42}$. Po fali protestów jedna z firm, Miller Brewing Company, zażądała usunięcia swojego logo z plakatu ${ }^{43}$.

Poruszenie wywołane reklamą pokazało, że zarówno wizerunek Jezusa, jak i, szerzej, symbole religijne, zostały bez reszty zawłaszczone przez konserwatywny

${ }^{34}$ Hipoteza ta została obalona, pisze o tym między innymi profesor Fr.W. Anders, por. idem, Kim była Maria Magdalena?, http://wuw.jezus.com.pl/uydarzenia/magazyn/kimbylamariamagdalena,wyd,fok,060329.html (dostęp: 14.10.2010).

${ }_{35}$ M. Poprzęcka, op. cit.

36 The Last Suppers, http://voyage.typepad.com/china/2005/10/the_last_supper.html, tłumaczenie własne (dostęp: 17.11.2009).

37 Ibidem.

${ }^{38}$ Ibidem.

${ }^{39}$ Wśród nich znalazła się między innymi znana drag queen, Sister Roma, por. http://www. thesisters.org/bios/roma.html (dostęp: 17.03.2010).

${ }^{40}$ http://www.cufa.org/articledisplay.asp?id=13888\&department=CFI\&categoryid=family. tłumaczenie ułasne (dostęp: 10.03.2010).

${ }^{41}$ Polskie określenie leather community użyte przez Janusza Boguszeuicza, por. idem, Sado-maso, czyli czy byłeś grzeczny, http://wuw.homiki.pl/modules.php?name=Neus\&file=article\& sid=2375 (dostęp: 17.10.2010).

42 "Gays” mock Jesus with Last Supper Take-off, http://www.cufa.org/articledisplay. asp?id=13888\&department=CFI\&categoryid=family, tłumaczenie własne (dostęp: 10.10.2010).

${ }^{43}$ Queering the Last Supper, http://jesusinlove.blogspot.com/2007/10/queering-last-supper. html (dostęp: 11.09.2017). 
odłam społeczeństua, który nie godzi się na jakiekolwiek ich uykorzystanie poza pierwotnym kontekstem. Najprostszą drogą jest interpretowanie omawianego plakatu jako prowokacji i obrazy uczuć religijnych. Bardziej płodne wydaje się jednak zastanowienie, w jak interesujący sposób autor fotografii, Fred Alert, podejmuje dyskusję ze stereotypami tak silnie obecnymi w kulturze. Reinterpretacja Ostatniej Wieczerzy jego autorstua to „charakterystyczna reprezentacja różnorodności”" ${ }^{\text {, }}$ obok siebie zasiedli przedstawiciele wszelkich orientacji seksualnych o różnych kolorach skóry ${ }^{45}$. Alert, tworząc uspółczesną wersję Ostatniej Wieczerzy, zadaje pytanie o to, kim dziś byłby Jezus oraz kogo wybrałby na swoich uczniów.

International Organization For Animal Protection sięgnęła w 2008 roku po znany z Ostatniej Wieczerzy motyw, by zwrócić uwagę na ponury los zwierząt porzucanych przez ludzi. W kojarzonej z obrazu da Vinci scenie głowy ludzi zostały zastąpione łbami psów. Jedynie Judasz został przedstawiony z twarzą człowieka. Zastosowany zabieg podkreślił hasło towarzyszące kampanii: „Jeden z was nas zdradzi” ${ }^{46}$ i wiąże się ściśle ze zdradą Judasza, do której zostaje przyrównane porzucanie towarzyszących ludziom zuierząt.

Motyw Ostatniej Wieczerzy jest często wykorzystywany w przekazach reklamouych, formy jego przetworzeń są różnorodne - od nawiązań uprost stanowiących jedynie dostosowanie przedstawienia znanego z obrazu da Vinci do celów reklamodawcy po inspiracje zaleduie tytułem obrazu. Ze spuścizny dzieła korzystają firmy, organizacje i producenci reprezentujący różnorodne usługi. Nawiązania do Ostatniej Wieczerzy można obserwować w reklamach między innymi odkurzaczy Dirt Devil, klocków Lego, portugalskiej firmy Lactogal produkującej nabiał, La Table Event Catering - firmy cateringowej, czasopisma lifestyleowego Freestyle, telewizorów z systemem High Definition, telewizji Fox, kawiarni u malezyjskim Kuala Lumpur, ale też środków na owady i szczury (Raid i Mortein Rat Kill), firmy Paddy Power, umożliwiającej zakłady przez Internet i rosyjskojęzycznej wyszukiwarki internetowej Rambler. Wśród organizacji nawiązujących do Ostatniej Wieczerzy znalazła się również poszukująca wolontariuszy portugalska Fundacao Evangelizacao e Culturas. Przytoczone przykłady dobitnie ukazują, jak szeroko wykorzystywanym, obecnym w pouszechnej świadomości motywem jest zobrazowany przez da Vinci biblijny moment Ostatniej Wieczerzy.

\section{Wnioski}

Będąca znakiem uspółczesności desakralizacja życia ${ }^{47}$ sprzyja sięganiu przez kulturę popularną po elementy zarezerwowane dotychczas dla sfery sacrum. Jednocześnie

${ }_{44}$ Folsom Street Events launches poster design for 24th annual Folsom Street Fair, http:// uwu.folsomstreetfair.com/fair-press.php?relNum=77, tłumaczenie własne (dostęp: 10.03.2010).

${ }^{45}$ Ibidem.

${ }^{46}$ http://wuw.advertolog.com/ipa/print-outdoor/one-of-you-betrays-us-12544155/, tłumaczenie ułasne (dostęp: 11.09.2017).

${ }^{47}$ M. Czerwiński, Pytając o cywilizacje, W.A.B., Warszawa 2000, s. 29. 


\section{Aleksandra Joanna Smorawska}

dziś to centra handlowe stają się świątyniami, w których ludzie szukają zaspokojenia swoich potrzeb i poczucia uspólnoty. Te zjawiska prowadzą do przedrzeźniania, wypaczania i doprowadzania do absurdu kodów czy scenariuszy religijnych ${ }^{48}$, które po uproszczeniu ${ }^{49}$ zostają wchłonięte przez kulturę popularną. Zjawisko to trafnie ujęła Katarzyna Krzan: „Mistyka staje się modna, popularna, jest trendy. Przenika do sfer, które [...] trudno podejrzewać o głębsze, duchowe treści" ${ }^{50}$.

Uprawnione jest tłumaczenie obecności elementów sfery sakralnej w kulturze popularnej także tym, że „reklama [...] chętnie odwołuje się do gotouych, już istniejących wzorców, konwencji, obrazów, symboli, stereotypów”51. Reklama wykorzystuje pouszechnie rozpoznawalną ikonografię, korzystając z tego, że, jak stuierdza Zbigniew Mikołejko, ludzie wierzą u „boskie ikony, zmysłowe przejawy, które łatuo sobie wyobrazić, zobaczyć na obrazku. Wierzą w Maryję i Jezusa, ale już nie bardzo w Ducha Świętego czy Boga Ojca. Nawet studenci humanistyki myślą, że Trójca Śuięta to Maryja, Dzieciątko i Józef"52. Symbole, dotychczas religijne, zostają odarte z przynależnego im kontekstu, a tracąc suój uśuięcony charakter mogą stać się pustymi znakami i „,kolejnym produktem skomercjalizowanej kultury” ${ }^{53}$. Kluczowe w obliczu gwałtownych reakcji na uykorzystywanie elementów sfery sakralnej przez kulturę popularną jest to, że „uszystkie zamachy na świętość nie obrażają Boga, a jedynie (?) naszą religijną wrażliwość, a czasami - nadurażliwość" ${ }^{4}$. Zabieg ten, pozwalając konkretnym grupom zająć antagonistyczne wobec siebie stanowiska - w obronie wolności słowa lub przeciuko możliwej obrazie uczuć religijnych, sprawia, że grupy te włączają się w dyskusję przysparzającą rozgłosu reklamowanym produktom czy usługom.

Strategia shockvertisingu pozwala z jednej strony na skuteczniejsze przyciągnięcie uwagi odbiorcy i wywołanie w nim emocji, z drugiej - na włączenie przekazu reklamowego $w$ debatę publiczną $w$ kontekście przekraczania granic, łamania tabu. Oliviero Toscani zuraca uwagę na to, że „reklama staje się niewidoczna”, a sięganie po elementy ze sfery sakralnej bywa skuteczną próbą przykucia uwagi znudzonego odbiorcy, zurócenia jego zainteresowania ku marce w sytuacji, gdy tradycyjna reklama odebrała konsumentowi apetyt ${ }^{55}$. Reklamowe przekazy naruszające

${ }_{48}$ B. Dobroczyński, III Rzesza Popkultury i inne stany, Instytut Wydawniczy Znak, Kraków 2004, s. 12.

${ }^{49}$ R. Horowitz [w:] Ł. Radwan, Jezus ogrodowy, „Wprost” 2008, nr 44, s. 127.

${ }^{50}$ K. Krzan, Ekstaza w wersji pop. Poszukiwania mistyczne w kulturze popularnej, WAiP, Warszawa 2008, s. 15.

51 D. Czaja, Reklamowy smak raju: między archetypem a historia, „Polska Sztuka Ludowa. Konteksty" 1994, nr 1-2, s. 73.

${ }^{52}$ A. Klich, Bóg z instrukcją obstugi „Użyj i wyrzuć”, http://wyborcza.pl/1,76498,8863908,Bog_z_instrukcja_obslugi_Uzyj_i_wyrzuc_.html (dostęp: 11.09.2017).

${ }^{53}$ K. Krzan, op.cit., s. 149.

54 A. Draguła, Kreowanie obrazu, http://tygodnik.onet.pl/32,0,7994,2,artykul.html (dostęp: 1.04.2011).

${ }_{55}$ O. Toscani, Reklama uśmiechnięte ścierwo, tłum. M. Misiorny, Delta, Warszawa 2009, s. 13. 
tabu tak silnie angażują uwagę odbiorcy, że nie jest on u stanie przejść obok tychże reklam obojętnie ${ }^{56}$.

Poruszenie i protesty pojawiające się w obliczu publikacji reklam reinterpretujących elementy sfery sakralnej pokazują nieumiejętność odróżnienia przez protestujących artystycznych wizji i kompozycji od prawdziwych rekwizytów czy symboli stanowiących sacrum. Jak pisze Francois Boespflug: „Wygląda na to, że bez głębszej analizy przyznaliśmy prawo symbolizowania wiary [...] schematom kompozycyjnym" ${ }^{57}$.

Twórcy reklam posługują się dobranymi u przemyślany sposób, najbardziej rozpoznawalnymi i nośnymi motywami oraz symbolami. Anna Ryłko-Kurpieuska zuraca uwagę na funkcje pełnione przez uspomniane nawiązania - bez wątpienia pozwalają one uytuorzyć reklamodawcom „rodzaj uspólnoty z odbiorcami” oraz dają grupie docelowej poczucie satysfakcji z rozpoznania intertekstualności nawet, jeśli jest ona jedynie powierzchowna, sprawiają też, że przekaz, z punktu widzenia odbiorcy, staje się mniej natarczyuy ${ }^{58}$. Satysfakcja ta może zachodzić na wielu poziomach rozumienia tekstu pierwotnego i jego obecności w nowym komunikacie, od wychwycenia podobieństu przez próbę zrozumienia intencji reklamodawcy, aż po krytyczną i twórczą dyskusję oraz poczucie znalezienia się $u$ roli eksperta z racji zauważenia i zrozumienia mechanizmu funkcjonowania znanego dzieła w nowym kontekście.

Analizując związki sfery sakralnej z kulturą popularną, łatwo wymienić negatywne skutki, trudniej pokusić się o refleksję pozualającą stuierdzić, że „kultura popularna i sakralna uspółpracują ze sobą coraz częściej, tworząc symbiotyczny związek wzajemnie się uspierający i uzupełniający" ${ }^{29}$.

\section{Podsumowanie}

Przedstawiona analiza nie wyczerpuje bogactua dostępnego materiału ikonograficznego, jednak różnorodność badanych tekstów pozuala twierdzić, że są one reprezentatyune dla zjawiska pojawiania się elementów sfery sakralnej w przekazach reklamowych. Dobór tekstów poddanych analizie pokazuje dobitnie, jak różne branże sięgają po symbolikę sfery sakralnej, by promować swoje produkty i usługi.

Dalszym krokiem i polem kolejnych badań może być analiza występowania elementów sfery sakralnej w reklamie dystrybuowanej za pomocą innych niż druk nośników. Można oczywiście pokusić się także o analizę przebogatej reklamowej ikonosfery pod kątem innych typów przedstawień sakralnych. Pole wartościouych i ciekawych badań daje nie tylko szeroka gama tekstów, które mogą zostać poddane analizie. Ważne jest również pokazanie ich wielowymiarowości, źródeł i mechanizmów

\footnotetext{
${ }^{56}$ Mitologie popularne. Szkice z antropologii wspótczesności, red. D. Czaja, TAiWPN Universitas, Kraków 1994, s. 163.

${ }^{57}$ F. Boespflug, cyt. za: A. Draguła, Kreowanie obrazy, http://tygodnik.onet.pl/32,0,7994,2,artykul. html (dostęp: 1.04.2011).

58 A. Ryłko-Kurpieuska, Reklama jako sztuka powtórzeń, Novae Res, Gdynia 2016, s. 114-115.

${ }^{59}$ K. Krzan, op. cit., s. 25.
} 


\section{Aleksandra Joanna Smorawska}

rządzących satysfakcją, jaką daje odbiorcy rozpoznanie odwołania do znanego tekstu kultury, a jednocześnie jego uproszczenia, zredukowania pierwotnego znaczenia ${ }^{60}$. Nie bez przyczyny w reklamach mamy do czynienia z najbardziej zakorzenionymi w pouszechnej świadomości symbolami kierującymi skojarzenia odbiorcy ku dobrze znanym dziełom.

\section{Bibliografia}

\section{Druki zwarte}

Burszta W.J., Kuligouski W., Dlaczego kościotrup nie wstaje. Ponowoczesne pejzaże kultury, Sic!, Warszawa 1999.

Czerwiński M., Pytając o cywilizację, W.A.B., Warszawa 2000.

Dmitruk K., Kultura popularna [w:] Stownik literatury popularnej, red. T. Żabski, wyd. II, Wydawnictuo Uniwersytetu Wrocłauskiego, Wrocław 2006.

Dmitruk K., Koraleuska E.K., Kultura popularna [w:] Stownik literatury popularnej, red.

T. Żabski, uyd. I, Touarzystwo Przyjaciół Polonistyki Wrocłauskiej, Wrocłau 1997.

Dobroczyński B., III Rzesza Popkultury i inne stany, Instytut Wydawniczy Znak, Kraków 2004. Krajeuski M., Kultury kultury popularnej, Wydawnictwo Naukowe UAM, Poznań 2005.

Krzan K., Ekstaza w wersji pop. Poszukiwania mistyczne w kulturze popularnej, WAiP, Warszawa 2008.

Leksykon podstawowych pojęć religijnych. Judaizm. Chrześcijaństwo. Islam, red. A.T. Khoury, PAX, Warszawa 1998, s. 905-910, hasło: sacrum.

Mały stownik religioznawczy, red. Z. Poniatouski, Wiedza Pouszechna, Warszawa 1969, s. 388, hasło: sacrum.

Mitologie popularne. Szkice z antropologii współczesności, red. D. Czaja, TAiWPN Universitas, Kraków 1994.

Niedałtouski K., Zawsze Ostatnia Wieczerza, Wydawnictwo Książkowe Tuój Styl, Warszawa 2006.

Osińska B., Sztuka i czas. Od prehistorii do rokoka, WSiP, Warszawa 2004.

Powszechna Encyklopedia Filozofii, t. 8, Polskie Towarzystwo Tomasza z Akwinu, Lublin 2007, s. 889-893, hasło: sacrum.

Religia. Encyklopedia PWN, t. 9, red. T. Gadacz, B. Milerski, Wydawnictuo Naukowe PWN, Warszawa 2003, s. 22-25, hasło: sacrum.

Ryłko-Kurpieuska A., Reklama jako sztuka powtórzeń, Novae Res, Gdynia 2016.

Słownik literatury popularnej, red. T. Żabski, wyd. I, Towarzystwo Przyjaciół Polonistyki Wrocłauskiej, Wrocław 1997.

Stownik literatury popularnej, red. T. Żabski, wyd. II, Wydawnictwo Uniwersytetu Wrocławskiego, Wrocław 2006.

Smorauska A., Sacrum w reklamie. Analiza przykładów wykorzystania elementów sfery sakralnej $w$ wybranych przekazach reklamowych, praca licencjacka napisana w Instytucie Filozofii, Socjologii i Dziennikarstua od kierunkiem prof. UG dr hab. A. Ryłko-Kurpieuskiej.

${ }_{60}$ Za punkt wyjścia można przyjąć próbę rozpoznania, czy reklama odwołuje się do faktycznego tekstu kultury, czy może raczej do pouszechnego o nim wyobrażenia, por. A. Ryłko-Kurpieuska, op. cit., s. 120 . 
Strużycki M., Heryszek T., Nowoczesna reklama na wspótczesnym rynku, Difin, Warszawa 2007.

Sztuka świata, t. 5, red. P. Trzeciak, Arkady, Warszawa 2004.

Toscani O., Reklama uśmiechnięte ścierwo, tłum. M. Misiorny, Delta, Warszawa 2009.

Wiedza o reklamie, praca zbiorowa, Wydawnictuo Szkolne PWN, Warszawa-Bielsko-Biała 2009.

\section{Czasopisma}

Czaja D., Reklamowy smak raju: między archetypem a historia, „Polska Sztuka Ludowa. Konteksty" 1994, nr 1-2.

Poprzęcka M., Ciuchy i świętość, „Gazeta Wyborcza” 2005, 7-8 maja.

Radwan Ł., Jezus ogrodowy, „Wprost” 2008, nr 44.

\section{Źródła internetowe}

Anders Fr.W., Kim była Maria Magdalena?, http://www.jezus.com.pl/wydarzenia/magazyn/ kimbylamariamagdalena,uyd,fok,060329.html (dostęp: 14.04.2010).

Boguszewicz J., Sado-maso, czyli czy byteś grzeczny, http://www.homiki.pl/modules. php?name $=$ Neus\&file $=$ article\&sid $=2375$ (dostęp: 17.03.2010).

Draguła A., Kreowanie obrazy, http://tygodnik.onet.pl/32,0,7994,2,artykul.html (dostęp: 1.042011).

Folsom Street Events launches poster design for 24th annual Folsom Street Fair. http://www. folsomstreetfair.com/fair-press.php?relNum=77 (dostęp: 10.03.2010).

"Gays" mock Jesus with Last Supper Take-off, http://www.cufa.org/articledisplay. asp?id=13888\&department=CFI\&categoryid=family (dostęp: 10.03.2010).

http://www.advertolog.com/die-12-apostel/print-outdoor/the-last-supper-5638905/ (dostęp: 11.09.2017).

http://wuw.advertolog.com/guestline-hotels/print-outdoor/last-supper-1812055/ (dostęp: 20.12.2010).

http://www.advertolog.com/ipa/print-outdoor/one-of-you-betrays-us-12544155/ (dostęp: 11.09.2017).

http://www.advertolog.com/marithe-francois-girbaud/print-outdoor/marithe-francois-girbaud-5392305/ (dostęp: 5.09.2017).

http://wuw.cufa.org/articledisplay.asp?id=13888\&department=CFI\&categoryid=family (dostęp: 10.03.2010).

http://wuw.thesisters.org/bios/roma.html (dostęp: 17.03.2010).

Klich A., Bóg z instrukcją obstugi „Użyj i wyrzuć”, http://wyborcza.pl/1,76498,8863908,Bog_z_instrukcja_obslugi_Uzyj_i_wyrzuc_html (dostęp: 11.09.2017).

Leonardo da Vinci - „Ostatnia Wieczerza”, http://www.italia-italia.info/021_ultimacena.htm (dostęp: 8.08.2017).

Ostatnia Wieczerza w popkulturze, http://www.joemonster.org/art/13690/Ostatnia_Wieczerza_w_popkulturze (dostęp: 30.12.2010).

Queering the Last Supper, http://jesusinlove.blogspot.com/2007/10/queering-last-supper.html (dostęp: 11.09.2017).

The Last Suppers, http://voyage.typepad.com/china/2005/10/the_last_supper.html (dostęp: 17.11.2009). 